\title{
Ophelia Unbound in Asian Performances
}

\section{Alexa Alice Joubin}

\section{(2) OpenEdition \\ Journals}

\section{Electronic version}

URL: http://journals.openedition.org/shakespeare/4887

DOI: $10.4000 /$ shakespeare.4887

ISSN: 2271-6424

\section{Publisher}

Société Française Shakespeare

\section{Electronic reference}

Alexa Alice Joubin, "Ophelia Unbound in Asian Performances », Actes des congrès de la Société française Shakespeare [Online], 37 | 2019, Online since 10 June 2019, connection on 26 June 2019 URL : http://journals.openedition.org/shakespeare/4887 ; DOI : 10.4000/shakespeare.4887

This text was automatically generated on 26 June 2019.

(C) SFS 


\title{
Ophelia Unbound in Asian Performances
}

\author{
Alexa Alice Joubin
}

Shakespeare reaches modern audiences through performances that contribute to the aesthetic liberation from interpretative conventions. Adaptations of Shakespearean tragedies in Asia, in particular, negotiate with dominant ideologies about Shakespeare's place in world literature. Stage and film directors leverage Shakespeare's own propensity to undermine dominant ideologies of gender-notably through the Ophelia figure-in their effort to renew Asian performance traditions and to carve a space for their works, drawing audiences from within and beyond Asia. This article works from an archive of recent performances to demonstrate the idea that the Shakespearean corpus becomes "unbound" when moved across cultures. Forms of performance are revised along with cultural ideologies in new interpretations.

2 In particular, Shakespeare's Ophelia becomes "unbound" in feminist performances that reinterpret traditional victimhood. Historically, each generation offers their reading of key characters. In the 1980s, feminist criticism and new historicism gradually replaced the paradigm of New Criticism. Texts are brought out of a New Critical vacuum to be situated in social and political contexts. As Susan Bennet notes, "the stories that now get told by way of readings of Shakespeare's [...] texts, are different stories from those that were told in 1980." Ophelia is one of the iconic characters that has gone through the most radical reinterpretations. In the history of reception, Ophelia has been an important icon of female victimhood. For example, French philosopher Gaston Bachelard connects a particular form of femininity, water imagery, and drowning in his theory of the Ophelia complex. $^{2}$

While critics have attended to the temporal axis of the vicissitudes literary criticism such as the feminist turn in the 1990s, this article examines the cultural axis of changing images of Ophelia on stage and on screen. A large part of Ophelia's global afterlife has remained inaccessible because of language and cultural barriers. While the stage and screen are governed by different formalistic features, they do share significant ideological vocabularies, especially in the case studies chosen for analysis in this article 
where stage productions draw on cinematic language and where film narratives are driven by stage performances.

The figure of Ophelia symbolizes a young woman who is vulnerable yet powerful, undermined and empowered by her femininity. We turn to Asian performance traditions, because East Asia is a region where femininity and feminism can take a paradoxical form. ${ }^{3}$ Although Asian Ophelias may suffer from what S. I. Hayakawa calls "the Ophelia syndrome" (inability to formulate and express one's own thoughts), they adopt various rhetorical strategies-balancing between eloquence and silence-to let themselves be seen and heard. ${ }^{4}$

Ophelia has a central place as a symbol of abuse victim in popular and performance cultures, but her story is often taken out of the Shakespearean context of signification. Two different sets of high-thread count cotton bedding are sold in China and Taiwan under the name "Ophelia," and the packaging-catering to the high-end marketassociates the name with quality, joy, and modern life. Ophelia is also the name of a selfmade heroine with compassionate instincts in a Chinese online video game of basketball that has little to do with any Shakespearean source. Douglas Lanier has attributed the presence of Shakespeare in contemporary popular culture to the film boom of the $1990 \mathrm{~s}$ while acknowledging that despite the broader audience for Shakespeare, the consumers' interest may not always lie in the Shakespearean canon. ${ }^{5}$ As examples in this article will illustrate, Ophelia has emerged as an icon that can sometimes be disconnected from the Hamletian context.

6 Twenty-first-century Asian adaptations tend to interpret Shakespearean tragedies through issues of spirituality and through the artists' personal, rather than national, identities. For example, in the dramatic traditions of Asian cultures with a Confucian inheritance, while women's agency is often undermined, women gain an upper hand when they return as ghosts or mediators in religious contexts.

\section{Historical Patterns of Interpretations of Ophelia}

7 Along with the rise of Korean feminism in the 1990s, several South Korean adaptations of Hamlet recast Ophelia as a shaman who serves as a medium to console the dead and guide the living. Since a shaman is outside the Confucian social structure, she has greater agency. The action of Kim Jung-ok's Hamlet (1993) takes place under an enormous hemp cloth that is suspended from the ceiling to resemble a house of mourning. It is customary for a mourning son to wear coarse hemp clothing, because hemp cloth is associated with funerals. Appropriately enough, the play begins with Ophelia's funeral. Possessed by the Old King's spirit, Ophelia conveys the story of his murder. Kim Kwang-bo's Ophelia: Sister, Come to My Bed (1995) also opens with Ophelia's funeral. Caught between the incestuous love of Laertes and the romantic love of Hamlet, Ophelia is eventually abandoned by both men: there is no future with Laertes, and Hamlet must carry out his revenge mission. Ophelia is possessed by the dead king's spirit: she urges Hamlet to avenge his father's death. When the ghost of old Hamlet appears, in the form of a large puppet operated by three monks, Ophelia moves in unison with the ghost and changes her voice to that of an old man. The dual soundtrack is unsettling. The use of shamanism as a thematic device creates a pathway to agency through ghosts. 
Japan's Yukio Ninagawa often draws on metatheatricality as a theme in his productions. He prepares the audiences to take on the play-world through pre-show action (e.g. in The Tempest and Titus Andronicus) and through creative visual framing devices (Hamlet). Before curtain time for Titus, audiences rubbed shoulders with actors in Roman costumes who were warming up and walking in the aisles. In the 1995 Hamlet (similar to the 2015 Hamlet) , the audience saw actors busy preparing for the performance in cubicles in the dressing rooms on stage before the show started. Ophelia followed the Japanese custom of arranging ornate hina dolls-a pastime for ladies at the court and now part of the Dolls' Festival in March celebrated by Japanese families. The dolls will eventually be set afloat to carry misfortunes away so that the family's daughters can grow up healthily and happily. Since the dolls represent hope, Ophelia's giving away dolls rather than flowers in her mad scene carried a grave suggestiveness. The metaphorical connection between drowningdolls adrift-and despair was also evident. In the play-within-a-play scene, performers sat on a tiered platform resembling a hina dolls cabinet. They formed a human tableau and drew attention to the artificiality of the performance. The audience's attention was redirected away from the representational aspect of theatrical realism to the presentational aspect of Ninagawa's metatheatrical narrative.

These stage performances are precursors to key films we will examine. This survey of Ophelia in East Asian performance traditions prepares us for case studies in the next section, which shall demonstrate three patterns of contemporary interpretations of the Ophelia figure, namely gender-bending performances, her involvement in politics, and a form of assertive victimhood.

\section{Gender-Pending Performance: The King and the Clown}

The figure of Ophelia has also been framed in gender-bending queer performances. Directed by Lee Joon-ik, the 2005 South Korean feature film The King and the Clown echoes various elements in Hamlet. ${ }^{6}$ The film is not a straightforward adaptation of the Shakespearean tragedy, though Adele Lee has argued that it can be seen as a retelling of Hamlet "from the perspective of the traveling players," turning the Shakespearean tragedy inside out.7 Set in the fifteenth century Joseon Dynasty, the film depicts the homoerotic entanglement among King Yeon-san and two street acrobat performers, the macho Jang-saeng and the effeminate Gong-gil. The king hires a group of vagabond traveling players to help him catch the conscience of corrupt court officials. The film thrives on the tension between theatrical presentation (play-within-a-play in the genre of namsadang nori) and cinematic narrative (which is the fabula of the film itself). The "mousetrap" play gradually supersedes the cinematic framework to become the primary, more interesting narrative.

Of special interest is how the narrative revolves around Gong-gil, an Ophelia-like figure, whose presence is a catalyst for the twists and turns of the plot. Gong-gil, the titular clown, attempts suicide and lies in a pool of his blood. His innocence contrasts with the straight male characters' calculation and intrigues, though his innocence also turns him into an object of male gaze.

The female impersonator Gong-gil evolves into an Ophelia figure as the film's narrative unfolds, particularly when he wears a Beijing opera headdress in a protracted playwithin-the-film scene, where the flowers on his head call to mind not only Ophelia's 
flower picking and flower wreath, but also the figure of flower boy in Korea, Japan, China, and Taiwan. The flower boy, or kkonminam, refers to an effeminate singer or actor whose gender presence is fluidly androgynous.

The film could be read as a political thriller or a homosexual love story. Over time, King Yeon-san, himself a composite Hamlet and Claudius figure, grows affectionate with Gonggil who plays female parts onstage and continues to present as female while offstage. One of the king's concubines, Jang Nok-su, becomes jealous of Gong-gil who seems to be replacing her as the king's favorite subject, or yi. At the same time, Gong-gil's long time street performance partner Jang-saeng also grows resentful toward Gong-gil's special status in the court. The king is clearly drawn to Gong-gil's appearance as an exotic object, while Gong-gil seems to hold the unhappy king in his sympathy. King Yeon-san frequently asks Gong-gil to put on private shows involving finger puppets in his chamber. As time passes, the king is enamored not only of Gong-gil's effeminate appearance but also his pure nature and kindness, qualities that are rare among the concubines, courtiers, and officers in the king's court.

King Yeon-san goes back and forth between his concubine Nok-su and the clown (player), Gong-gil. It is unclear what the king's emotional needs are. In one intimate scene, the king displays symptoms of Oedipal complex when Nok-su says "come to mama, poor baby wants mama's milk." The king rests his head on her lap. We can see parallels to Hamlet's self-emasculation in the act 3 scene 2 with Ophelia. In contrast to Nok-su as mother and lover, Gong-gil can be seen as the Ophelia figure as he replaces Nok-su in the king's court.

At one point the concubine taunts Gong-gil about his "real" gender. She tries to undress Gong-gil in front of the king, creating a great deal of tension. Gong-gil does not say a word and seems rather docile in this moment when he is expected to protest the concubine Jang Nok-su's pent-up anger. The concubine's motives are two-fold. She is jealous of the newcomer who replaces her as the king's favorite subject. She is also frustrated by Gong-gil's impersonation of femininity. The king eventually uses brute force to throw her out of the room to protect Gong-gil. The concept of drag may not apply here, as Gong-gil is not only in drag when in performances but remains in female presentation in daily life. A parallel example would be early modern English boy actors' careers. There are multiple cases of successful boy actors, such as Richard Robinson and Edward Kynaston, who played female roles on stage and transitioned to playing male roles when they grew up. Boyhood was presented as androgynous and gender fluid, but interestingly, as Simone Chess theorizes, these boy actors carried a "queer residue" with them into male adulthood as they continue to perform feminine or androgynous roles. ${ }^{8}$ Kynaston is probably the best known among them in modern times thanks to Samuel Pepy's diary (August 1660) and the feature film Stage Beauty (dir. Richard Eyre, 2004).

Like Kurosawa's uses of traditional Japanese theatrical elements in his films, The King and the Clown draws attention to Korean theatrical traditions by frequently placing an emphasis, ironically, on the stage rather than the screen as a medium of expression. Gong-gil's presence provides a powerful framing to the idea of the artificiality of performance-of gender, history, and genre. 


\section{Political Entanglements}

17 In contrast to the gender queer Gong-gil, the Ophelia figure in the Bollywood film Haider bends politics rather than gender. Directed by Vishal Bhardwaj and written by the Kashmiri journalist Basharat Peer, Haider (UTV Motion Pictures, India, 2014; in Hindi and Urdu) is one of the latest Asian adaptations offering explicit and subtler parallels and echoes of Shakespeare's Hamlet. The figures of Rosencrantz and Guildenstern can be seen in the video-store owners (Suman and Suman) in the film, while the hatchback-driving, talented, journalist Arshia finds herself on a path leading toward Ophelia's tragic life thanks to her father and brother. The daughter of a local policeman named Pervez (Polonius), Arshia plays a more significant role than just Haider's (Hamlet) love interest. Roohdaar, a double agent, sends a message for Haider through Arshia concerning Hilaal Meer (old Hamlet) who has been detained and tortured for information on militants. Haider returns to Kashmir from Aligarh in search of his father, only to discover his uncle Khurram (Claudius) is having an affair with his mother.

Meanwhile, the Hamlet figure Haider's life experience and identity are full of paradoxes. The film engages with the notion of duality. Haider's Muslim family sends him away to university in the hope that he would not be religiously and politically radicalized. A student of "revolutionary poets of British India" (as he tells the Indian guard at the checkpoint), Haider returns a radicalized intellectual to his homeland of militarized Kashmir in the midst of mid-1990s Pakistan-India conflicts upon the news of his dissident father's disappearance. Even the props carry this duality.

This Ophelia figure finds herself at the center of familial and political entanglements. Arshia (Ophelia) knits her father a red scarf, which he often wears proudly. However, the same scarf is used to tie up Haider's hands in a later scene. The director spares no chance in drawing attention to the symbolism of knitting and the scarf. In a later scene, Arshia lies beneath a web of red wool from the unpicked scarf. The image foreshadows her own emotional unraveling, because, partly, the wool is a stylized symbol of blood.

While this is a film, this scene calls to mind Peter Brook's 1955 production of Titus Andronicus and Yukio Ninagawa's use of similar imagery in his 2006 production of the same play. In stylized presentations inspired by Asian forms, flowing red fabric is associated with female victims on stage whether it is Ophelia in Haider or Lavinia in Titus. Starring Laurence Olivier, Brook's Titus Andronicus is one of the landmark productions that rehabilitated the tragedy. It transformed Titus from an undervalued melodrama to a study of primitive forces that can be taken seriously. In the scene of Lavinia's mutilation, scarlet streamers flow from her mouth and wrists to symbolize her rape and violation. This production anticipated the use of red ribbons as symbols of blood in Japanese director Ninagawa Yukio's 2006 production in Stratford as part of the RSC Complete Works festival. Ninagawa treated the play as myth, because recurring ritual in a cycle is best understood through symbolism. In Haider, Arshia agonizes over the fact that she reveals damaging information about Haider to her father, a police inspector. In the end, Arshia commits suicide over her father's death. The red scarf she is working on becomes her own entrapment.

21 Politics means there are always more than two sides to the story, and Arshia's death remains ambiguous. Many scenes, shot on site in Kashmir, are largely devoid of colors and overwhelmed by the weight of politics. The rolling intertitles at the end of the film 
bring us back to our contemporary reality. The information given here is largely positive and hints at the reconciliation between India and Pakistan over the territorial conflict:

In the last two decades, thousands of lives have been lost in the Kashmir conflict. The last few years of relative peace have renewed hope. With tourism growing from just 4.2 million tourists in 1995 to 140 million tourists in 2013.

Self-conscious about the film's portrayal of the Indian soldiers, the filmmaker decides to provide a counterbalance:

In the recent devastating floods in Kashmir, the Indian army saved the lives of thousands of civilians. We salute their efforts and their valour. Principal photography for this film was entirely conducted in Kashmir without any disruptions.

This Ophelia is unbound from traditional interpretations of her silenced role, but she is bound in Kashmir politics.

\section{Assertive Victimhood}

We turn to paradoxical female empowerment and assertive victimhood in our last section. An innocent yet assertive Ophelia emerges from Chinese director Feng Xiaogang's 2006 The Banquet (aka The Legend of the Black Scorpion), a high-profile kung fu period epic set in fifth-century China with an all-star cast. Feng is a household name in China, known for his invention of a new genre, the comic and often farcical "New Year celebration film" screened during the Chinese New Year. Highly profitable and entertaining, the genre subverts the didacticism that is standard fare in films produced by state studios. The Banquet's Ophelia (Qing Nü, played by Zhou Xun) dominates many scenes with her songs and dance, and is not shy about expressing her affection for Hamlet (Prince Wu Luan, played by Daniel Wu) even when she is threatened by the Gertrude figure (Empress Wan, played by Zhang Ziyi), who is both the prince's step-mother and lover. Significantly, Ophelia does not go mad. While her songs allude to rivers and boating, and her intimate scene with Hamlet involves rain, Ophelia is not drowned in the end.

This bold cinematic re-imagination of Hamlet shifts the focus from the question of interiority-traditionally embodied by Hamlet-to an ambitious, articulate Gertrude (Empress Wan) and an assertive Ophelia (Qing Nü): both characters do not hesitate to express their love for the prince. Empress Wan is the prince's stepmother and she has kept her romantic relationship with him under wraps. Qing Nü's naïveté and purity make her a desirable yet unattainable figure of hope, in contrast to the calculating empress, and as an ideal contrast to China's post-socialist society, driven by a new market economy that turns everything, including romance and love, into a commodity. ${ }^{9}$ Instead, she is innocent, passionate, and bold.

Despite China's economic growth, censorship continues to pose a challenge to artists. In the film, Qing Nü shuns traditional methods of communication altogether. In response to Empress Wan's probing question as to whether Qing Nü has received any letters from the prince, she offers a bold answer: "we never exchange letters." She also speaks of her dreams openly: "The prince always comes in my dreams. He came last night as well." She admits this with a sense of pride. Significantly, for a martial arts film, Qing Nü is the only character not versed in 
swordsmanship, and her only weapons are her perseverance in the face of insurmountable obstacles and headstrong adherence to her love for the prince. Her name, Qing Nü, derives from the goddess of snow in Chinese mythology, and her robes are always white regardless of the occasion. This highlights the idea of chastity, as snow is used as a trope for chaste women in traditional poetry. ${ }^{10}$ Qing Nü is uninterested in politics, and refuses to succumb to her father's advice to "learn from the empress" and use marriage as a political stepping-stone. Empress Wan, by contrast, marries her brother-in-law in exchange for power and security after her husband is killed by a scorpion's sting. Yet Qing Nü's innocence and dedication do not translate into childishness. In response to her brother's reminder that "you are not in [the prince's] heart. Do not fool yourself," Qing Nü indicates that she is fully aware of the situation, but she has "promised to always wait for him." She chooses to stay by his side and sing to him so that he will not be lonely. The consequences are painful. Jealous of Qing Nü's intimacy with the prince and her ability to offer unconditional love, Empress Wan orders her to be whipped. Ever defiant and refusing to be manipulated by anyone, Qing Nü almost gets her face branded and is exiled to the south by the Empress.

Qing Nü also publicly expresses her love for the prince. When Wu Luan is being sent by Emperor Li as a hostage to the Khitans, a nomadic people in northwestern China, Qing Nü petitions in front of the court to be allowed to go along, echoing Desdemona's insistence on accompanying Othello to Cyprus. Her passions are uncensored, and her reasons simple: so that the prince will not be lonely. Unlike Shakespeare's Ophelia Qing Nü does not have to go mad or speak allusively to express herself, though she sings on multiple occasions just like Ophelia does in Hamlet. Toward the end of the film at the banquet celebrating the coronation of the empress, she sings a song of solitude that the prince had taught her, and leads a group dance:

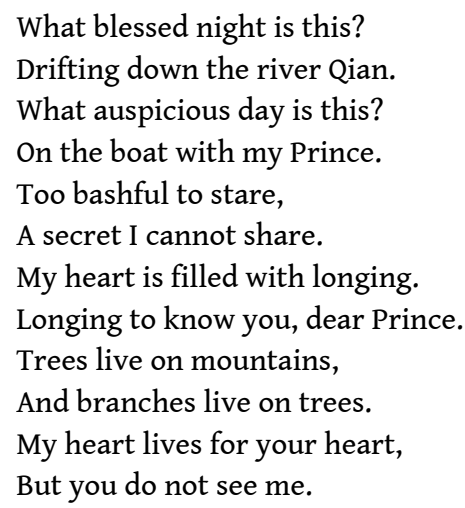

This is a song of solitude. She seems to be content to simply love the prince without seeking anything in return. Qing Nü's entrance takes Emperor Li and Empress Wan by surprise: her performance at the court commemorates her lover who has been presumed dead en route to the Khitans (although, unbeknownst to Qing Nü and everyone in the court, the prince has returned and is disguising himself as one of the masked dancers).

Qing Nü's accidental death at the hands of the Empress has more in common with Shakespeare's Claudius or Gertrude than Ophelia: she drinks from a poisoned cup the Empress intends for the Emperor. Ever a saintly presence, Qing Nü addresses her last words to the prince: "Do you still feel lonely?" Mourning Qing Nü's demise, the prince, a kung fu master, finally moves forward with his revenge plan. Ophelia's fatal drop from the willow tree into the stream in Hamlet is thus replaced by Qing Nü's selfless sacrifice and symbolic purging of the court's collective sins in The Banquet. 
The Ophelia figure therefore represents ideal femininity in the face of a dysfunctional courtly structure and in opposition to Hamlet's ambiguous gender identity. No longer a "green girl" (1.3.101), Ophelia speaks freely for herself.

In terms of visual strategy, Asian films have been known to draw on a wide range of sources, including renowned paintings such as John Everett Millais's famous Ophelia (1851) which was exhibited in Tokyo, Kobe, and elsewhere and is well-known to East Asian audiences. One of the themes of the painting is the cycle of growth and decay. Ophelia is portrayed as being in the transitional moment between life and death. Buoyed temporarily by the stream, the dying Ophelia is half sunk but her head is still above the water. Extending upwards, her open arms at first glance may resemble the traditional pose of a martyr at the moment of her death.

Shot in Tibet with an all-Tibetan cast, Sherwood Hu's Prince of the Himalayas offers a fuller, visual response to Millais's representation of the drowning Ophelia. Tibetan actress Sonamdolgar as Odsaluyang presents a feisty and assertive Ophelia who links the secular with the sacred, and death with life. Ophelia is associated with water throughout the film. Early on, we are shown a rather explicit, intimate scene between Prince Lhamoklodan (Hamlet) and Odsaluyang in her hut by a stream, after which Ophelia becomes pregnant (the two are not married). In labor, Odsaluyang approaches the Namtso Lake, a sacred site to Tibetan pilgrims, in search of the prince, whom she loves, but also hates, for killing her father. It seems that she walks into the lake to ease her pain, but the scene presents a haunting image of Ophelia's death that amounts to a visual citation of Millais's painting. Picking wild flowers and wearing a white garment with a floral wreath on her head, she lies down and floats on water, giving birth to her and Hamlet's child before "sinking down to the river bed in deep sleep" where she "meets her father and mother" (Pang, 54). The camera pans over the water to give us a glimpse of the baby floating away from the mother. Presumably she dies after giving birth in the lake, but her death is not depicted on screen.

This scene takes Ophelia's association with the cyclic quality of nature in Millais to a different level, hinting at the necessary, if cruel, procession of fading and emerging generations. This scene is depicted in a painterly mode in Hu's film to focus attention on Ophelia's suffering. As Odsaluyang walks into the lake singing a song, the water runs red with her blood. The baby is carried by water to safety, rescued by the Wolf Woman, a prophet. As one of the most interesting departures from Hamlet, this scene hints at the possibility of a saintly Ophelia who, in her death, brings forth a new life and hope for the next generation. Prince of the Himalayas offers a courageous, independent Ophelia.

If Gertrude's account of Ophelia recasts her as a fairy-tale creature ("mermaid-like," 4.7.176), Odsaluyang in Prince of the Himalayas is a kind of goddess of nature, an immortal bride who returns to Nature. The strong association between water and suffering women in Chinese art and film history contributed to Hu's decision to shoot Ophelia's death scene by the mirror-like Namtso Lake near Lhasa. Water might play the role of a mirror of beauty or a gateway to darker realities lying beneath its surface. Female water deities celebrated in Chinese poetry and paintings "ruled the waves" and water can play the role as either "a mirror of beauty or for the darker possibilities hidden below its surface" (Silbergeld, 175). Hu's film associates Ophelia with a water goddess not unlike the Luo River Goddess or the Goddesses of the Xiang River. She is a source of danger but also of rebirth. Such goddesses, according to legends, start out as "unhappy spirits of drowned victims involved in female sacrifice, young girls given in local rituals as brides to pacify 
male river gods. Others may have been romantic love suicides (nobly following their deceased husbands) ... or victims of no-love situations... while still others represented punishment for female sexual transgression" (175). Prince of the Himalayas literally gives birth to a more sexual as well as spiritual vision of Ophelia in the water.

\title{
Conclusion: The Double Bind of Ophelia
}

\author{
Last thing he did, dear queen, \\ He kissed-the last of many doubled kisses- \\ This orient pearl. \\ -Antony and Cleopatra (1.5.45-48)
}

The image of Ophelia may be unbound in feminist performances in a global context, but the circulation of these works remain bound by political circumstances and market realities. Not all adaptations have an equal stage and channels of circulation. Over the past two decades, numerous performances recast Shakespeare and Asia as condensed collective signifiers of cultural values through their double marketability for audiences in different locations. Outside their country of origin, these films attract audiences who are enthralled by the performance of the exotic, whether it's Shakespearean or Asian motifs. Within their local market, the name brand of an editorialized Anglophone Shakespeare helps to boost their production value. Filmmakers see the co-presence of Shakespearean and Asian motifs as an asset, as "double kisses." They use selective cinematic elements, such as conventionalized Bollywood dance and Chinese martial arts sequences, as common denominators and bonding agents between different periods and cultures.

Further, filmmakers, whatever their "origin," working with Asian motifs, aesthetics, or outlooks often have to contend with their own aesthetic or political visions and their regionally marked cultural identity. Their works respond to the competing demands to be simultaneously inhabiting the local and the global; in other words, to represent "Asia" on the world market and to be the conveyor of a "global West" to Asian audiences. Similar to Shakespeare Must Die, which was banned in Thailand (even though, ironically, the Culture Ministry's Office of Contemporary Art and Culture partially funded the production), Haider has a limited distribution in Asia and did not pass the Pakistani censor. It is, however, screened in the US and UK. Haider is now available on DVD with English subtitles and is reasonably easy to obtain in Canada, the US, and UK. The same could not be said of other Asian Shakespeare films which are not available on VCD or DVD, do not have subtitles (in any language), or are not easy to obtain even if they have been commercially released.

The double visions in Asian adaptations are perhaps not surprising, because Shakespearean tragedy is often constructed on a framework of mighty opposites and sometimes irreconcilable differences. These adaptations suggest the rise of local aesthetics in the post-national marketplace. The double identities and visions of these Asian performances are at once exciting and confusing. Scholars have debated about the dual visions of such works. The real challenge is not in pinpointing what an artwork is (a cultural imperialist project or a site of cultural redemption), but rather how artistsacross time and culture-listen to and respond to one another.

With these double visions, Asian rewritings transform Ophelia from "a document of madness" (4.5.178) to symbols of purity, female agency with limits, and an icon of true love. While her songs still occupy the center of attention, Ophelia does not tend to stand 
in for lost girlhood or female madness in the Asian context. Instead, the strands of girl power and fragile girlhood coexist as Asian Ophelias lay claim to their moral agency. The figure of Ophelia is sometimes pitched as a cross between a conscientious and filial Cordelia, an innocent Desdemona, a loyal subject, and a fearless and dedicated lover.

As a result, the figure of Ophelia becomes "unbound" through a long history of performances that carry conflicting interpretations. As Fredric Jameson argues in his latest book Allegory and Ideology, works do not have innate meanings but rather "soak up meanings" as they move through the world (1). The brief history of the contemporary images of Ophelia presented here suggests that Ophelia is a discursive site of simultaneous, sometimes contradictory, meanings. Distinct from liberal pluralism or cultural relativism, this process of unbinding-as a process that sorts multiple meaningssupports ideological struggles.

\section{NOTES}

1. Susan Bennett, Performing Nostalgia: Shifting Shakespeare and the Contemporary Past, London, Routledge, 1996, p. 27.

2. Gaston Bachelard, L'eau et les rêves; essai sur l'imagination de la matière, Paris, J. Corti, 1942.

3. Rey Chow, Woman and Chinese Modernity: The Politics of Reading Between West and East, Minneapolis, University of Minnesota Press, 1991.

4. S. I. Hayakawa, "What Does It Mean to Be Creative?" Through the Communication Barrier, ed. Arthur Chandler, New York, Harper \& Row, 1979, p. 104-105.

5. Douglas Lanier, Shakespeare and Modern Popular Culture, Oxford, Oxford University Press, 2002, p. 3-4.

6. Lee Joon-ik, The King and the Clown (Wang-ui namja), South Korea, Eagle Pictures, 2005.

7. Adele Lee, "The Player King and Kingly Players: Inverting Hamlet in Lee Joon-ik's King and the Clown (2005)", Borrowers and Lenders: The Journal of Shakespeare and Appropriation 12.1 (Fall 2018), http:// www.borrowers.uga.edu/784121/show

8. Simone Chess, “Trans Residue: Nonbinary Affect and Boy Actors' Adult Careers." Shakespeare Association of America annual meeting, Washington, D.C., April 2019.

9. Jason McGrath, Postsocialist Modernity: Chinese Cinema, Literature, and Criticism in the Market Age, Stanford, Stanford University Press, 2008, p. 1-24.

10. Ciyuan (Chinese Dictionary of Etymology), Revised Edition, ed. Shangwu yinshuguan Editorial Committee. Beijing, Shangwu yinshuguan, 1997, p. 1823. 


\section{ABSTRACTS}

Asian directors leverage Shakespeare's own propensity to undermine dominant ideologies of gender-notably through the Ophelia figure-in their effort to renew Asian performance traditions. How do Shakespeare and modern directors talk to each other across cultural and historical divides? How does Ophelia become "unbound" through supralinguistic structures of spectacle and music? With case studies of three Hamlet films: Haider (India, 2004), The King and the Clown (South Korea, 2005), and Prince of the Himalayas (Tibet, 2006), this article examines how Asian films negotiate with Asian cultural norms, ideas of Ophelia as an iconic victim, and the image of Hamlet as a brooding male intellectual. Outside their country of origin, these films attract audiences who are enthralled by the performance of the exotic, whether it's Shakespearean or Asian motifs. Within their local market, the name brand of an editorialized Anglophone Shakespeare helps to boost their production value. Filmmakers see the co-presence of Shakespearean and Asian motifs as an asset, as "double kisses." They use selective elements, such as conventionalized Bollywood dance and Chinese martial arts sequences, as common denominators and bonding agents between different periods and cultures.

Comment de nouvelles images d'Ophélie émergent-elles des scripts et discours narratifs modernes? Certains metteurs en scène asiatiques ont choisi de tirer parti de la propension de Shakespeare à saper l'idéologie dominante sur le rôle des femmes, notamment à travers le personnage d'Ophélie, afin de renouveler la tradition théâtrale asiatique. Quel dialogue existe-t-il entre Shakespeare et les metteurs en scène contemporains au-delà des fossés historiques et culturels? Avec l'analyse de trois adaptations d'Hamlet (Haider, Bollywood, 2004; Le roi et le clown, Corée, 2005; et Prince de l'Himalaya, Tibet, 2006), cet article se propose d'examiner l'approche que prennent ces productions sur l'image d'Ophélie comme victime emblématique ainsi que sur les normes culturelles asiatiques. En dehors de leur pays d'origine, ces films attirent un public fasciné par un certain exotisme, qu'il soit shakespearien, de motif asiatique, ou une combinaison des deux. Au sein de leur marché local, l'image de marque d'un contenu shakespearien d'origine anglophone renforce une valeur ajoutée prestigieuse. L'utilisation par ces metteurs en scène de conventions cinématographiques spécifiques, tels que la danse bollywoodienne, ou encore les séquences d'arts martiaux chinois, sert de dénominateur commun et de liant entre différentes périodes pour aboutir à une double identité culturelle.

\section{INDEX}

Mots-clés: adaptation, appropriation, cinéma asiatique, théâtre asiatique, Bollywood, féminisme, culture populaire, Corée du Sud, Tibet

Keywords: adaptation, appropriation, Asian cinema, Asian theatre, Bollywood, feminism, gender fluidity, popular culture, South Korean, Tibetan 
AUTHOR

ALEXA ALICE JOUBIN

George Washington University 